\title{
The Potential of Sumatran Pine Rosin (Gondorukem) for Reinforcement-Steel Coating in Wet Environment
}

\author{
Rudi Hartono ${ }^{1}$, Bagyo Yanuwiadi ${ }^{2}$, Lukman Hakim ${ }^{3}$ \\ 1 Post Graduate School of Environmental and Development, Brawijaya University, Malang, Indonesia \\ ${ }^{3}$ Department of Biology, Faculty of Science, Brawijaya University, Malang, Indonesia \\ ${ }^{2}$ Department of Chemistry, Faculty of Science, Brawijaya University, Malang, Indonesia
}

\begin{abstract}
The corrosion of reinforcement-steel due to the presence of water is commonly prevented by coating process. In this work, the potential of Sumatran Pine rosin (gondorukem) as a natural and environmentally-friendy resource to coat reinforcementsteel, and an initial assessment on its capability to prevent the corrosion in wet environment were investigated. The experiments were performed using two types of commercially available gondorukem, namely type $T$ and $U$. The coated reinforcement-steel samples were immersed in collected rainwater and their physical changes were observed periodically for 60 days. The results showed that gondorukem improve the durability of the reinforcement-steel from corrosion in a severe rainwater contact.
\end{abstract}

Keywords: Gondorukem, Corrosion, Coating, Hydrophobic, Reinforcement bar

\section{INTRODUCTION}

Corrosion is a serious problem for countries whose geographic conditions are surrounded by seawater with long coastlines and wet tropical climates such as Indonesia. Corrosion can deteriorate reinforcement-steel inside a concrete and it is hardly detected at initial stage. The loss due to the corrosion of concrete reinforcement-bar is enormous from the perspective of safety, cost, and environmental pollution. The economy impact is widely spread in the various sectors such as transportation, infrastructure, industrial, and residence [1].

The corrosion of reinforcement-steel in a concrete structure can be caused by water seepage and the aeration conditions inside the concrete. The prevention control is commonly done by coating the steel surface. This method has been done since 1970 using epoxy-coating, zinc coating, and cathodic protection. A new direction on the utilization of natural and environmentally friendly materials on steel protection against corrosion has been carried out [1-2]. Several natural and environmentally friendly materials for corrosion control have been reported, such as the tobacco extract for inhibitor corrosion in sea water [4], Phyllanthus muellerianus for reducing corrosion in concrete steel reinforcement in industrial and microbial environment [5], the extract of gingko biloba as a corrosion inhibitor for J55 steel [6], natural honey as a corrosion inhibitor on bronze by a weak acid [7], and biomolecules from bacteria cells [8].
The residual product of distillation process of Sumatran Pine (Pinus merkussi) sap is known as pine rosin, and locally termed as Gondorukem in Indonesia. The distillation process commonly yields $15-25 \%$ of turpentine oil, which is the main commercial interest, and left $70-80 \%$ of rosin. The study of rosin and its derivative [9] as a functional coating material is widely reported, from the civil engineering interest such as to improve asphaltconcrete durability and as a component in porous asphalt pavement [2], to pharmaceutical interest such as drug coating [10-11]. In Indonesia, gondorukem is widely used as an additive to the industrial products, such as adhesives, batik printing, soap, wax, vernish, and paper [12].

Gondorukem mainly consists of abietic acid and pimaric acid with $80-90 \%$ composition. Abietic acid and pimaric acid are hydrophobic or waterresistant [2]. In this work, the potential of gondorukem as a natural and environmentalfriendly coating material for reinforcement-steel was investigated, and an early qualitative evaluation to its capability in strengthening reinforcement-steel to withstand corrosion damage in wet environment was carried out.

\section{MATERIALS AND METHODS Materials}

Commercial gondorukem of type $\mathrm{T}$ and $\mathrm{U}$ (Indonesian National Standard, SNI No. 7636:2011) was used in this study. Type $T$ shows a dark brownish color and type $U$ shows a clear yellowish color. Standard concrete reinforcement-steel (SNI

Correspondence address: 
AISI 1020) with $7 \mathrm{~mm}$ in diameter and $60 \mathrm{~mm}$ in length was used as the corrosion subject.
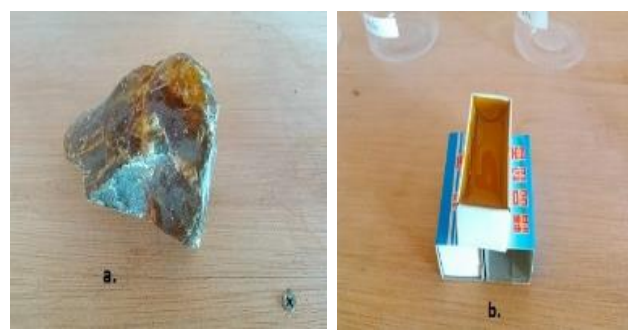

Figure 1. Physical appearance of gondorukem type T (left) and type $U$ (right).

\section{Steel coating process}

Solid gondorukem was ground to powder and then dissolved in xylene $99 \%$ solution with $1: 1$ mass ratio to produce liquid resin. The coating was done by immersing reinforcement steel into liquid resin for $10 \mathrm{~s}$, and dried in room temperature for $6 \mathrm{~h}$. The process was repeated to obtain multiple coatings. The average coating thickness was calculated by measuring the difference in mass and diameter of the steel, before and after the coating process.

\section{Corrosion test}

A sample of rain water was collected and used as an environment water for corrosion test. The test was carried out by immersing the coated steels in the rain water, and the surface condition was recorded periodically for 60 days. Uncoated reinforcement steel was used as a control, and a standard ASTM G1 test were carried out to calculate the corrosion rate of the uncoated reinforcement-steel sample.

\section{RESULT AND DISCUSSION}

The reinforcement-steel coating process with gondorukem was found to be relatively simple. The immersion and drying process of steel samples ( $n=$ 3 ) yields to a relatively uniform coating thickness with no sign of physical deterioration. The process can be repeated to obtain multiple coatings, and Figure 2 shows the calculated coating thickness, based on the difference in sample mass and diameter before and after the coating. The thickness was found to be linearly increased with each coating process, at least up to three layers in this study. Further coating to extend the number of layer is considered possible. Figure 2 also shows that, in general, gondorukem of type $T$ yields to a thicker layer compared to gondorukem of type $U$. The liquid resin of gondorukem $T$ was observed to be more viscous than gondorukem $\mathrm{U}$; thus led to a thicker layer.

The hydrophobic property of gondorukem coating is expected to hinder the contact between steel and environmental water that may seep through a concrete, and thus prevent the corrosion from taking place. An early evaluation to this capability was done qualitatively by immersing the coated gondorukem inside collected rain water samples and observe the occurence of corrosion. Uncoated steel samples were imposed to the same treatment as a control variable. The results are summarized in Table 1 . Heavy corrosion was observed on the uncoated steel samples that were immersed in rain water within the first 10 days (Figure 3, left). The standard ASTM G1 test indicates that the corrosion of uncoated steel sample reduces the life of the concrete with a corrosion rate of $0.832 \mathrm{~mm}$ / year. On the other hand, gondorukem-coated steel-samples were observed to withstand corrosion within the same 10 days. It is worth to be noted that the immersion of steel in collected rainwater is considered to be a more severe situation compared to the actual steel condition inside a concrete during rainy season. Table 2 also shows that the number of coating layers significantly improve the durability of the steel sample in general. With the possibility to

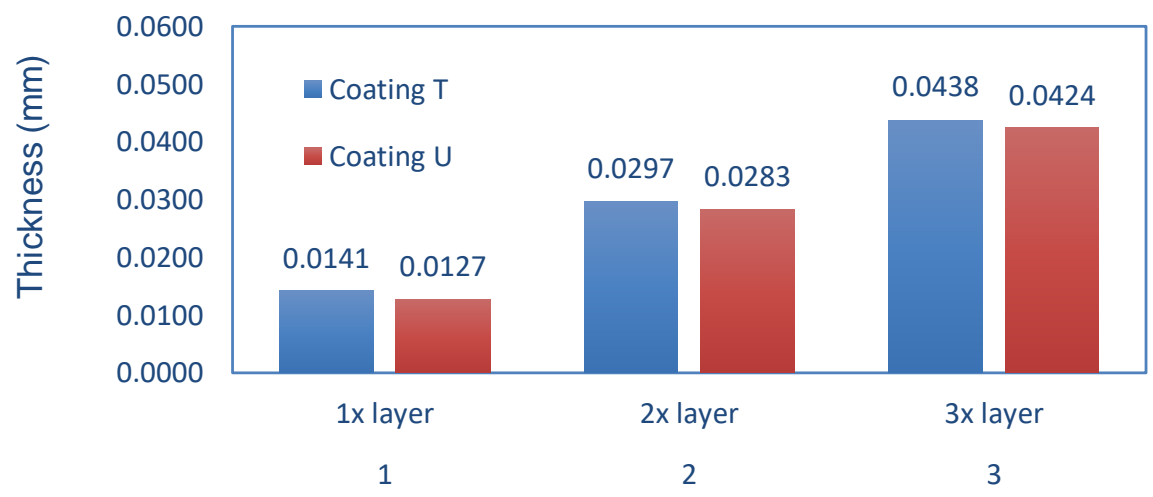

Figure 2. The thickness of gondorukem coating layers on reinforcement-steel sample 
extend the coating process to yield further beyond three layers, a better protection can be expected. Interestingly, while Figure 2 shows that gondorukem T coating is thicker than gondorukem $U$ coating in general, Table 1 shows that gondorukem $U$ has a better corrosion prevention. Within 60 days, no corrosion was observed in sample with double and triple gondorukem $U$ coating (Figure 3, right). Gondorukem T is evaluated as a residue with higher contaminants compared gondorukem $U$, thus two factors can be argued to correspond this observation, i.e. either the microscopical structure of gondorukem $\mathrm{T}$ layer enable rainwater to seep, or the the layer is prone to deterioration during long contact with rainwater.

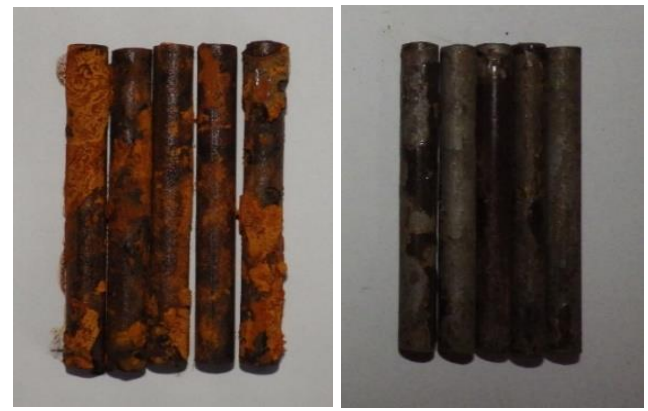

Figure 3. The physical appearance of steel samples after immersion in the collected rainwater. LEFT: uncoated steel after 10 days; RIGHT: gondorukem U coated samples after 60 days.

Table 1. The observation of corrosion occurence in the steel samples that are immersed in collected rain water. Samples coated with gondorukem $T$ is labeled as GT, and gondorukem $U$ is labeled as $\mathrm{GU}$. The number that immediately follows the code indicates the number of coating layers.

\begin{tabular}{ccccccc}
\hline $\begin{array}{c}\text { Samples } \\
(\boldsymbol{n}=\mathbf{3})\end{array}$ & $\mathbf{1 0}$ & $\mathbf{2 0}$ & $\mathbf{3 0}$ & $\mathbf{4 0}$ & $\mathbf{5 0}$ & $\mathbf{6 0}$ \\
\hline GT1 & $\mathrm{a}$ & $\mathrm{b}$ & $\mathrm{c}$ & $\mathrm{d}$ & $\mathrm{e}$ & $\mathrm{f}$ \\
GT2 & $\mathrm{a}$ & $\mathrm{b}$ & $\mathrm{b}$ & $\mathrm{c}$ & $\mathrm{d}$ & $\mathrm{d}$ \\
GT3 & $\mathrm{a}$ & $\mathrm{b}$ & $\mathrm{b}$ & $\mathrm{b}$ & $\mathrm{c}$ & $\mathrm{c}$ \\
GU1 & $\mathrm{a}$ & $\mathrm{b}$ & $\mathrm{b}$ & $\mathrm{b}$ & $\mathrm{c}$ & $\mathrm{d}$ \\
GU2 & $\mathrm{a}$ & $\mathrm{b}$ & $\mathrm{b}$ & $\mathrm{b}$ & $\mathrm{b}$ & $\mathrm{b}$ \\
GU3 & $\mathrm{a}$ & $\mathrm{b}$ & $\mathrm{b}$ & $\mathrm{b}$ & $\mathrm{b}$ & $\mathrm{b}$ \\
no coating & $\mathrm{g}$ & $\mathrm{g}$ & $\mathrm{g}$ & $\mathrm{g}$ & $\mathrm{g}$ & $\mathrm{g}$ \\
\hline
\end{tabular}

\begin{tabular}{ll}
\hline a coating color did not change and no corrosion is observed \\
b coating color changed to grey and no corrosion is observed \\
c corrosion cover less than $5 \%$ of area \\
d corrosion cover around $5-10 \%$ of area \\
e corrosion cover around $10-15 \%$ of area \\
f corrosion cover around $15-20 \%$ of area \\
g corrosion cover more than $20 \%$ of area
\end{tabular}




\section{CONCLUSION}

The potential of gondorukem as a coating material to strenghten the durability of reinforcement-steel in wet environment had been investigated. The simple coating process was able to yield a relatively uniform coating thickness, without any sign of physical deterioration, and the process can be repeated to obtain multiple coating layers. All gondorukem-coated steel samples showed better durability against corrosion when immersed in a collected rain samples. The durability was shown to be proportional to the number of coating layers. Gondorukem type U showed better protection compared to gondorukem type $\mathrm{T}$ in all tests, regardless the fact that gondorukem type $T$ yielded to a thicker coating. Gondorukem type $U$ with two and three coating layers, did not show any sign of corrosion within 60 days immersion in the collected rainwater, a condition which is more severe than the actual reinforcement-steel inside a concrete during rainy season.

\section{REFERENCES}

[1]. D. M. Richardson, 2000, Ecology and Biogeography of Pinus, Cambridge University Press, United Kingdom.

[2]. B. Wiyono, 2010, Teknologi Pengolahan Gondorukem Hidrogenasi dari Pengolahan Getah Pinus, Pusat Keteknikan Kehutanan dan Pengolahan Hasil Hutan, Bogor, Indonesia

[3]. B. D. B. Tiu, R. C. Advincula, 2015, Polymeric corrosion inhibitors for the oil and gas industry: Design principles and mechanism, React. Funct. Polym. 95, 25-45.

[4]. H. Wang, M. Gao, Y. Guo, Y. Yang, R. Hu., 2016, A natural extract of tobacco rob as scale and corrosion inhibitor in artificial seawater, Desalination, 398, 198-207.

[5]. J. Okeniyi et al, 2015, Investigating Prospects of Phylantus muellerianus as Ecofriendly/Sustainable Material for Reducing Concrete Reinforcement Steel Corrosion in Industrial/Microbial Environment, Ener. Procedia, 74, 1274-1281.

[6]. A. Singh, Y. Lin, E. E. Ebenso, W. Liu, J. Pan, B. Huang, 2015, Gingko Biloba Fruit Extract as an Eco-friendly Corrosion Inhibitor for J55 Steel in $\mathrm{CO} 2$ saturated $3.5 \% \mathrm{NaCl}$ Solution, J. Ind. Eng. Chem., 24, 219-228.

[7]. M.I. Gombos, 2016, Evaluation of Natural Honey as Corrosion Inhibit for Bronze in Weakly Acidic Solution, J. Young Scientist, 4, 33-38.

[8]. V. Shubina, L. Gaillet, T. Chaussadent, T. Meylheuc, J. Creus, 2015, Biomolecules as a sustainable protection against corrosion of reinforced carbon steel in concrete, J. Clean. Prod., 112, 666-671.

[9]. R.A. El-Ghazawy, A.M. El-Saeed, H.I. Al-Shafey, A.M. Abdul-Raheim, M.A. El-Sockary, 2015, Rosin based epoxy coating: Synthesis, identification and characterization, Euro. Polym. J., 69, 403-415

[10]. Y.V. Pathak, A.K. Dorle, 1987, Study of Rosin and Rosin Derivatives as Coating Materials for Controlled Release of Drug, J. Control. Release, 5, 63-68.

[11]. P.M. Satturwar, et al , 2004, Evaluation of new rosin derivatives for pharmaceutical coating, Int. J. Pharm, 270, 27-36.

[12]. Khadafi et al, 2014, Pengolahan Gondorukem Menjadi Bahan Pendarihan Sebagai Aditif pada Pembuatan Kertas, Jurnal Selulosa, 4, 17-24. 